\title{
Ameliorating Effect of Silicon on Growth Vigor, Physiological and biochemical Traits of Salinized Canola Seedlings (Brassica napus L.)
}

\author{
Rasha M. El-Shazoly * \\ Botany and Microbiology Department, Faculty of Science, New Valley University, 72511, Al-Kharja, New Valley, Egypt
}

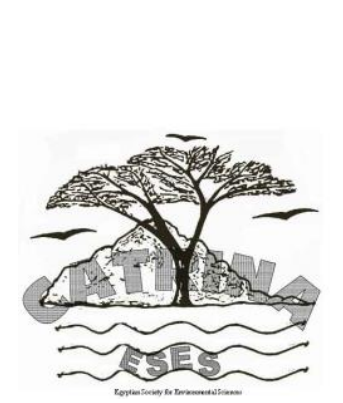

ABSTRACT
In the present study the ameliorating effects of Si nutrition supplied as $1 \mathrm{mmol} \mathrm{L}^{-1}$ sodium silicate were proved on the seedling growth of canola (Brassica napus L.) seedlings under salinity stress (i.e. 0, 30, 60, 90 and $120 \mathrm{mmol} \mathrm{L}^{-1}$ sodium chloride). Salinity obviously disrupted cellular homeostasis, something was evident in the decreased percent of scavenging $\mathrm{HO}^{-}$free radical and Metal chelating $\%$, and hence reduction in photosynthetic pigments contents (chl.a and carotenoids). Silicon nutrition, however, enabled canola cells to balance between the steady-state levels of different ROS through improving the detoxification of the excess ROS. This was prevalent in higher scavenging percent of $\mathrm{HO}^{-}$and metal chelating. In addition, Si maintained membranes integrity through improved levels of lipid peroxidation inhibition \%. Si buffered oxidative stress through sustaining the enzymatic and non-enzymatic scavenging capacity of reactive oxygen species in salt-stressed plants. Enzymatic antioxidants such as (CAT, SOD, APX, and POS) activities as well as non-enzymatic antioxidants such as carotenoids contents phenolics contents increased at $120 \mathrm{mmol} \mathrm{L}^{-1}$ sodium chloride. Thus, silicon nutrition alleviated the deleterious effects of salinity on the growth of canola plants through increased reactive oxygen species scavenging capacity (enzymatically and non-enzymatically), maintaining the membrane integrity of seedling cells as evidenced by raising the reducing power contents, sustained higher levels of chlorophyll. Consequently, enhance seedlings growth observations.

Keywords: salinity, silicon, antioxidant enzymes, lipid peroxidation inhibition $\%, \mathrm{HO}^{-}$radical scavenging $\%$, metal chelating $\%$.

\section{INTRODUCTION}

One of the major agricultural concerns is salinity as it is very deleterious abiotic stresses. The detrimental effects of salinity hinder plant growth and productivity. Soil salinity causes substantially or partially unproductive lands (Medellín-Azuara et al., 2014). Salt affected cultivated land is over 800 million hectares worldwide (Munns and Tester, 2008). The problems of saline soil and water have serious implications in irrigated agricultural systems, and soil degradation caused by salinity is major challenge globally (Qadir et al., 2008). Soil salinity occurs naturally or through agricultural practices. Among soluble salts, $\mathrm{NaCl}$ is the most soluble and dominant salt with adverse effects on various morphological, physiological and microbiological and molecular aspects at whole plant level (Pessarakli and Szabolcs, 2010). High salt concentrations of soil are often associated with ion imbalances and hyperosmotic pressure, which eventually lead to oxidative stress conditions for plants (Abideen et al., 2014). Purty et al., 2008 indicated that tolerance against salinity stress is a complex trait that is governed by interconnected mechanisms at elevated levels, cellular, tissue and organ. Numerous agronomic practices have been made to improve the salinity tolerance of a variety of crops in addition to physiological and genetical methods, but no satisfactory commercial success has been reached so far.

Canola (Brassica napus L.) is oil seed crop, which is increasingly used as a source of edible vegetable oil (Iniguez-Luy and Federico, 2011). Besides its uses in food applications, canola is mainly used to produce clean-burning biofuel (Zapata et al., 2012). Although maximum yields of canola are obtained under normal soil and environmental conditions, the quantity and quality of seed yields are affected by environmental stress (Singh et al., 2014). Improving the tolerance of canola to stressful conditions would lead to increased yields of higher quality oil. Canola is categorized as moderate salinity-tolerant crop (Ashraf and McNeilly, 2004).

Timely silicon ( $\mathrm{Si}$ ) is usually classified under the beneficial element category. It has proven effects in enhancing abiotic stress tolerance (Eraslan et al., 2008; Haghighi and Pessarakli, 2013), improving pest (Han et al., 2015) and increasing photosynthetic capacity and yield (Guntzer et al., 2011) in various crops. According to its abundance in the lithosphere, silicon is classified as second most abundant element (Broadley et al., 2002). However, silicon is still not recognized as an essential element for plant growth and development. Over the last few years, several reports have highlighted the positive effects of silicon ( $\mathrm{Si}$ ) fertilization in agriculture (Liang et al., 2015). Incidentally, the International Plant Nutrition Institute (IPNI) has recently added $\mathrm{Si}$ to its list of beneficial nutrients (Ouellette et al., 2017). Despite high abundance of silicon, it is never present in a free form in soil and is usually taken up by the plant as monosilicic acid $\left(\mathrm{Si}(\mathrm{OH})_{4}\right)(\mathrm{Ma}$ and Yamaji, 2006). Exact mechanism of $\mathrm{Si}$ involvement in metabolic or physiological process of plants has not yet been elucidated (Guntzer et al., 2011). More explored, however, have been the influences of $\mathrm{Si}$ in alleviating deleterious effects of salinity and its suggested mechanisms of action in some plant species including soybean (Lee et al., 2010), strawberry (Wang and Galletta, 1998) and tomato (Haghighi and Pessarakli, 2013). However, there is still a shortage of information available regarding the role of supplied $\mathrm{Si}$ in ameliorating salinity in terms of antioxidant defense system and cell damage of canola. 
The present work assigned to study the influence of salinity in the presence or absence of sodium silicate on vegetative growth attributes, chlorophylls content, lipid peroxidation inhibition \%, LOX enzyme, metal chelating $\%$, reactive oxygen species scavenging $\%\left(\mathrm{H}_{2} \mathrm{O}_{2}\right.$ and $\mathrm{OH}^{-}$), antioxidant enzymes (peroxidase, catalase, ascorbate peroxidase and superoxide dismutase) activities and some other physiological parameters (proteins, phenolics, flavonoids, reducing power and total antioxidants) in Sarw 4 canola cultivar.

\section{MATERIALS AND METHODS}

The seeds of canola (Brassica napus L.) cultivar Sarw 4, commonly used in Egypt, were kindly supplied by the Agricultural Research Center, Giza, Egypt. Seeds sterilized with $\mathrm{NaClO} 5 \%$ for 15 minutes and washed several times with distilled water and then spread on Petri dish $(100 \mathrm{~mm}$ x $15 \mathrm{~mm})$; lined with wet filter sheets. Canola seedlings were subjected to elevated $\mathrm{NaCl}$ levels $(0,30,60,90$ and $120 \mathrm{mM})$. Silicon treatment was $1 \mathrm{mM} \mathrm{Na} \mathrm{SiO}_{3}$ combined with $\mathrm{NaCl}$ levels as: $0+\mathrm{Si}, 30+\mathrm{Si}, 60+\mathrm{Si}, 90+\mathrm{Si}$, and $120+\mathrm{Si}$. Each Petri dish represented as an experimental unit with 25 seed. All experiments were performed in six replications. The seeds were covered in the dark at $24^{\circ} \mathrm{C}$. The roots length and shoots height were measured over the course of 8 days and compared to the untreated control. After measurement, whole seedlings were washed twice with distilled water, dried gently with filter paper. The seedlings were quickly weighted for fresh weight determination, then oven-dried at $70^{\circ} \mathrm{C}$ for 48 hours in order to determine dry weight.

\section{Preparation of the extract}

Another fraction of fresh seedlings was immediately weighted and ground in a chilled mortar and pestle with $5 \mathrm{ml}$ buffer solution containing Tris $\mathrm{HCl} \mathrm{pH} \mathrm{7,50mM,}$ containing $1 \mathrm{mM}$ sodium (EDTA) and $3 \mathrm{mM} \mathrm{MgCl}_{2}$. The extract was centrifuged at $4^{\circ} \mathrm{C}$ for $10 \mathrm{~min}$ at 5000 rpm. The resultant supernatant was used for the enzymatic and non-enzymatic antioxidants determinations in addition to antioxidant potential determinations.

\section{Photosynthetic pigment Determination}

The photosynthetic pigments were extracted from fresh plumule samples by suspending it in $5 \mathrm{ml}$ of $95 \%$ $\mathrm{C}_{2} \mathrm{H}_{5} \mathrm{OH}$ at $60^{\circ} \mathrm{C}$, until colorless. Then the total volume completed into $10 \quad \mathrm{ml}$ with $95 \% \quad \mathrm{C}_{2} \mathrm{H}_{5} \mathrm{OH}$ and absorbance readings were determined at 663, 644 and $452 \mathrm{~nm}$ spectrophotometerically. Chlorophylls and carotenoids concentrations were calculated as cited by Lichtenthaler (1987) as $\mathrm{mg} \mathrm{g}^{-1} \mathrm{FW}$.

\section{Determination of soluble proteins}

Protein contents were determined in the plant extract by Folin reagent according to Lowry et al. (1951). A calibration curve was constructed using bovine serum albumin (BSA) and the data were expressed as mg BSA $\mathrm{g}^{-1}$ fresh matter.

\section{Enzymatic antioxidants}

Superoxide dismutase assay

SOD activity Determination carried out according to of Beauchamp and Fedovich (1976) method. The amount of enzyme causing the reduction of NBT by $50 \%$ was expressed as SOD Unit. The expression of specific activity was in terms of units per mg of protein.

Catalase assay

CAT activity determination carried according to Aebi, (1984). The decrease in $\mathrm{H}_{2} \mathrm{O}_{2}$ absorbance at $\mathrm{A}_{240} \mathrm{~nm}$ was used to calculate the activity.

Guaiacol peroxidase assay

GPX activity determination carried out following the method of Tatiana et al. (1999). The increase in absorbance at $\mathrm{A}_{470} \mathrm{~nm}$ due to the formation of tetraguaiacol was measured.

Assay of Ascorbate peroxidase

APX activity was assayed following the method of Jiang and Zhang (2002). The decrease in $A_{290}$ following the oxidation rate of ascorbic acid was measured.

\section{Assay of Lipoxygenase}

The method of Minguez-Mosquera et al. (1993) was modified and used to assay lipoxygenase activity. The substrate was prepared by solubilizing $0.5 \mathrm{~g}$ linoleic acid with $0.5 \mathrm{~g}$ Tween 20 in deionized water and the final volume brought to $25 \mathrm{ml}$. Turbidity was cleared with a few drops of $2 \mathrm{~N} \mathrm{NaOH}$. The plant extract was reacted with the substrate in a spectrophotometer cuvette containing $3 \mathrm{ml}$ phosphate buffer $0.2 \mathrm{M}$, at $\mathrm{pH}$ 6.5 and the absorbance measured at $234 \mathrm{~nm}$ at $20 \mathrm{~s}$ intervals for $1 \mathrm{~min}$ using a recording spectrophotometer. The rate of formation of conjugated diene reaction products, measured as an increase in $\mathrm{A}_{234} \mathrm{~nm}$.

\section{Non enzymatic antioxidants determinations \\ Total phenolics determination}

Total phenolic contents were assessed according to Singleton and Rossi (1965). Folin-Ciocalteau reagent method was used. The measurements carried out at $\mathrm{A}_{765}$ $\mathrm{nm}$. Gallic acid equivalents were used to express the data as $\mu \mathrm{g} \mathrm{g}^{-1} \mathrm{FW}$ using Molar Coefficient of $120 \mu \mathrm{g}^{-}$ ${ }^{1} \mathrm{~cm}^{-1} \mathrm{ml}^{-1}$

\section{Total Flavonoids determination}

Content of total flavonoid was measured according to Moreno et al. (2000). Quercetin equivalents were used to express the absorbance at $\mathrm{A}_{415} \mathrm{~nm}$ as $\mathrm{mg} \mathrm{g}^{-1} \mathrm{FW}$.

Activity of total antioxidant

The contents of total antioxidant were measured according to Prieto et al. (1999). The absorbance was measured at $\mathrm{A}_{695} \mathrm{~nm}$.

Reducing power assay

The method of Oyaizu (1986) was used to detect reducing power of the plant samples. Ascorbic acid equivalents were used to express the absorbance at $A_{700}$ $\mathrm{nm}$ as $\mu \mathrm{g} \mathrm{g}^{-1} \mathrm{FW}$.

Hydroxyl radical $\left(\mathrm{OH}^{-}\right)$scavenging assay

$\mathrm{OH}^{-}$radical scavenging assay carried out according to Kunchandy and Rao, (1990). Absorbance of plant 
was measured against a blank containing deoxyribose and buffer at $\mathrm{A}_{532} \mathrm{~nm}$, and degradation inhibition of deoxyribose was used to calculate the inhibition in percent (I) was calculated by the formula

\section{$\mathrm{I}=($ Abs control - Abs sample $) /$ Abs control X 100}

\section{Hydrogen peroxide $\left(\mathrm{H}_{2} \mathrm{O}_{2}\right)$ scavenging}

$\mathrm{H}_{2} \mathrm{O}_{2}$ radical scavenging assay carried out according to Long et al. (1999). Sodium pyruvate was used as the reference compound. The absorbance of the ferricxylenol orange complex was measured at $\mathrm{A}_{560} \mathrm{~nm}$.

\section{Lipid peroxide formation inhibition}

lipid peroxidation inhibition \% carried out according to Janero (1990). The absorbance of the upper organic layer was measured at $A_{532} \mathrm{~nm}$. The inhibition in percent (I) was calculated by the formula

\section{$\mathrm{I}=($ Abs control - Abs sample $) /$ Abs control X 100}

\section{Metal chelating assay}

Metal chelating ability carried out according to Decker and Barbara (1990). The absorbance of the solution was measured at $\mathrm{A}_{562} \mathrm{~nm}$. EDTA was used as a positive control.

\section{Statistical analysis}

The experiments were simple in complete Randomized (CR) design. Each treatment replicated in six Petri dishes. One-way ANOVA was performed on the data from two independent experiments with three replicates. The expressions of data as (mean \pm SE). Analysis performed using the SPSS statistical 11.0 package. Comparing of means for significant differences Duncan's multiple range tests at $(p<0.05)$ were used. All the assessed attributes subjected to cluster analysis using a Correlations similarity distance with the software PAST version 2.11 for Windows (Hammer et al., 2001). The matrix was then analyzed with Principle Component Analysis (PCA) variance regression ordination, using the Sørensen coefficient as the distance measure, to check the magnitude of change in attributes along the $\mathrm{NaCl}$ and $\mathrm{NaCl}+\mathrm{Si}$ gradients by the same software.

\section{RESULTS}

\section{Ameliorative effect of $\mathrm{Si}$ on canola seedling growth under $\mathrm{NaCl}$ stress}

Salinity led to a significant reduction in fresh mass, while, exogenous Si treatment had a positive effect on fresh mass of NaCl-stressed seedlings (Table 1). Generally, the canola growth was completely stopped under $120 \mathrm{mM} \mathrm{NaCl}$, while Si treatment sustained the survival of the seedlings under this concentration. Dry matter showed different trend towards elevated concentrations of salinity with or without $\mathrm{Si}$ application. Generally significant raise in dry matter was observed at elevated concentration of salinity, except for $120 \mathrm{mM}$ $\mathrm{NaCl}+\mathrm{Si}$ where a significant reduction occurred.

As shown in table (1), salinity stress significantly decreased the shoot and root length, which was more prevelant in roots. In contrast, Si external application significantly enhanced the growth of shoots and roots.

The inhibitory effect of salinity can be observed in photosynthetic pigments as represented in table (1). Precisely, Ch.a and carotenoids contents decreased gradually with the rise of $\mathrm{NaCl}$ concentrations, while Ch.b content fluctuated under the elevated $\mathrm{NaCl}$ concentrations. On the other hand $1 \mathrm{mM}$ Si promoted significant higher content of Ch.a, Ch.b, and carotenoids under different salinity levels as compared to $\mathrm{NaCl}$ levels without $\mathrm{Si}$.

Table (1): Growth attributes of canola (Brassica napus L. cultivar Sarw 4) as influenced by $\mathrm{NaCl}(\mathrm{mM})$ stress and silicon (1 mM $\mathrm{Na}_{2} \mathrm{SiO}_{3}$ ), different letters are significantly different at $\mathrm{p}<0.05$, (mean $\pm \mathrm{SE} ; \mathrm{n}=3$ ).

\begin{tabular}{|c|c|c|c|c|c|c|c|c|}
\hline \multicolumn{2}{|c|}{$\begin{array}{c}\text { NaCl Conc. } \\
\text { mM }\end{array}$} & \multirow{2}{*}{$\begin{array}{c}\begin{array}{c}\text { Fresh Wt. } \\
\text { g plant }^{-1}\end{array} \\
0.039 \pm 0.0029^{\mathrm{e}}\end{array}$} & \multirow{2}{*}{$\begin{array}{c}\begin{array}{c}\text { Dry Wt. } \\
\text { g plant }^{-1}\end{array} \\
0.0020 \pm 0.0001^{\mathrm{b}}\end{array}$} & \multirow{2}{*}{$\begin{array}{c}\begin{array}{c}\text { Plant height } \\
\text { Cm }\end{array} \\
2.97 \pm 0.15^{\mathrm{c}}\end{array}$} & \multirow{2}{*}{$\begin{array}{c}\begin{array}{c}\text { Root length } \\
\text { Cm }\end{array} \\
1.50 \pm 0.09^{\mathrm{b}}\end{array}$} & \multirow{2}{*}{$\begin{array}{c}\begin{array}{c}\text { Ch.a } \\
\text { mg g }^{-1} \mathbf{F W t} .\end{array} \\
86.3 \pm 2.0^{\mathrm{f}}\end{array}$} & \multirow{2}{*}{$\begin{array}{c}\begin{array}{c}\text { Ch.b } \\
\text { mg g }^{-1} \text { FWt. }\end{array} \\
5.2 \pm 0.3^{\mathrm{d}}\end{array}$} & \multirow{2}{*}{$\begin{array}{c}\begin{array}{c}\text { Carot. } \\
\text { mg g }^{-\mathbf{1}} \mathbf{F W t} .\end{array} \\
41.6 \pm 0.9^{\mathrm{f}}\end{array}$} \\
\hline Control & Zero & & & & & & & \\
\hline & 30 & $0.028 \pm 0.0014^{\mathrm{d}}$ & $0.0022 \pm 0.0002^{\mathrm{c}}$ & $2.07 \pm 0.10^{\mathrm{b}}$ & $0.37 \pm 0.09^{\mathrm{a}}$ & $62.1 \pm 2.1^{\mathrm{d}}$ & $6.1 \pm 0.4^{\mathrm{e}}$ & $32.5 \pm 1.2^{\mathrm{d}}$ \\
\hline \multirow[t]{4}{*}{ Without Si } & 60 & $0.022 \pm 0.0013^{\mathrm{c}}$ & $0.0027 \pm 0.0001^{\mathrm{g}}$ & $1.13 \pm 0.07^{\mathrm{a}}$ & $0.53 \pm 0.07^{\mathrm{a}}$ & $48.4 \pm 3.2^{c}$ & $3.0 \pm 0.3^{c}$ & $27.9 \pm 2.0^{\mathrm{c}}$ \\
\hline & 90 & $0.014 \pm 0.0013^{\mathrm{b}}$ & $0.0023 \pm 0.0001^{\mathrm{d}}$ & $1.03 \pm 0.10^{\mathrm{a}}$ & $0.20 \pm 0.07 a$ & $4.2 \pm 1.0^{\mathrm{a}}$ & $6.9 \pm 0.2^{f}$ & $7.0 \pm 0.7^{\mathrm{a}}$ \\
\hline & $\mathrm{Zero}^{+\mathrm{Si}}$ & $0.039 \pm 0.0014^{\mathrm{e}}$ & $0.0028 \pm 0.0001^{\mathrm{h}}$ & $3.40 \pm 0.11^{\mathrm{c}}$ & $4.57 \pm 0.17^{\mathrm{d}}$ & $97.7 \pm 3.0^{\mathrm{g}}$ & $9.6 \pm 0.5^{g}$ & $46.5 \pm 0.6^{\mathrm{g}}$ \\
\hline & $\mathbf{3 0}^{+\mathrm{Si}}$ & $0.039 \pm 0.0011^{\mathrm{e}}$ & $0.0024 \pm 0.0001^{\mathrm{e}}$ & $3.10 \pm 0.15^{\mathrm{c}}$ & $4.53 \pm 0.09^{d}$ & $113.6 \pm 3.4^{\mathrm{h}}$ & $14.3 \pm 0.3^{\mathrm{i}}$ & $54.8 \pm 0.7^{\mathrm{i}}$ \\
\hline \multirow[t]{3}{*}{ With Si } & $60^{+S i}$ & $0.059 \pm 0.0024^{\mathrm{g}}$ & $0.0025 \pm 0.0001^{\mathrm{f}}$ & $4.23 \pm 0.10^{\mathrm{d}}$ & $2.07 \pm 0.07^{\mathrm{c}}$ & $122.9 \pm 2.0^{\mathrm{i}}$ & $11.8 \pm 0.3^{\mathrm{h}}$ & $58.1 \pm 1.0^{\mathrm{h}}$ \\
\hline & $90^{+\mathrm{Si}}$ & $0.048 \pm 0.0015^{\mathrm{f}}$ & $0.0031 \pm 0.0001^{\mathrm{i}}$ & $2.00 \pm 0.11^{\mathrm{b}}$ & $2.03 \pm 0.11^{\mathrm{c}}$ & $62.3 \pm 1.3^{\mathrm{e}}$ & $2.5 \pm 0.2^{\mathrm{b}}$ & $34.5 \pm 1.2^{\mathrm{e}}$ \\
\hline & $120^{+\mathrm{Si}}$ & $0.011 \pm 0.0010^{\mathrm{a}}$ & $0.0015 \pm 0.0001^{\mathrm{a}}$ & $0.93 \pm 0.07^{\mathrm{a}}$ & $0.27 \pm 0.06^{\mathrm{a}}$ & $17.8 \pm 1.0^{\mathrm{b}}$ & $0.6 \pm 0.1^{\mathrm{a}}$ & $9.1 \pm 0.5^{\mathrm{b}}$ \\
\hline
\end{tabular}

As shown in table (2), low salinity level (30 $\mathrm{mM})$ exhibited a significant reduction in phenolics content with or without silicon, compared to control. Higher sodium chloride $(60,90$, and $120 \mathrm{mM})$ concentrations plus or minus $\mathrm{Si}$ resulted in a significant rise in phenolics content. Salinity stress caused a significant decrease in the concentration of reducing power in canola seedlings (Table 2). Si treatment at 30 and 60 $\mathrm{mM} \mathrm{NaCl}$ gave a similar response to that given by the applied salinity treatment individually.

While the content of reducing power doubled at 90 $\mathrm{mM} \mathrm{NaCl}$ and even get higher at $120 \mathrm{mM} \mathrm{NaCl}$.
Application of $\mathrm{Si}$ at $0 \mathrm{mM} \mathrm{NaCl}$ caused induction in the content of total antioxidants in canola seedlings more than absolute control by about 2.34 fold as represented in table (2).

There has been an increase in the content of the total antioxidants at elevated salinity levels, whether or not adding silicon, but cannot deny the obvious improvement in the content of total antioxidants by adding silicon except for $60 \mathrm{mM} \mathrm{NaCl}$, which showed higher total antioxidants without $\mathrm{Si}$ application.

Flavonoids content were fluctuated under different salinity treatments with or without $\mathrm{Si}$ (Table 2). The 
lowest concentration $(30 \mathrm{mM} \mathrm{NaCl})$ hindered the production of flavonoids when compared to control, while elevated concentrations of $\mathrm{NaCl}(60$ and $90 \mathrm{mM})$ resulted in a significant induction in the flavonoids content. The external application of $\mathrm{Si}$ gave the same response, a reduction observed at (30 and $60 \mathrm{mM})$ $\mathrm{NaCl}$. The production of flavonoids enhanced significantly with the addition of $\mathrm{Si}$ at 90 and $120 \mathrm{mM} \mathrm{NaCl}$.

Lipid peroxidation inhibition \% (Table 2) showed a significant induction under 30 and $60 \mathrm{mM} \mathrm{NaCl}$ without $\mathrm{Si}$, while, a significant reduction can be observed at 90
$\mathrm{mM} \mathrm{NaCl}$. External application of Si improved significantly the inhibition percent of lipid peroxidation, when compared to control, or the corresponding salinity level without $\mathrm{Si}$, while the significant reduction was observed at $120 \mathrm{mM} \mathrm{NaCl}$ with Si treatment.

A significant increase was observed in the values of the hydroxyl radicle scavenging $\%$ under the salinity effect, which is more apparent when applying the silicon treatment (Table 2).While amendment with $\mathrm{Si}$ at $120 \mathrm{mM} \mathrm{NaCl}$ could not improve the significant retardation in the scavenging percent of hydroxyl radicle.

Table (2): Antioxidants and Free Radical Scavenging Activities of canola (Brassica napus L. cultivar Sarw 4) as influenced by NaCl (mM) stress and silicon $\left(1 \mathrm{mM} \mathrm{Na}_{2} \mathrm{SiO}_{3}\right)$, different letters are significantly different at $\mathrm{p}<0.05$, (mean $\left.\pm \mathrm{SE} ; \mathrm{n}=3\right)$.

\begin{tabular}{|c|c|c|c|c|c|c|c|c|c|}
\hline $\begin{array}{c}\mathrm{NaCl} \\
\text { Conc. } \\
\mathrm{mM}\end{array}$ & & $\begin{array}{l}\text { Phenolics } \\
\mu \mathrm{g} \mathrm{g}^{-1} \text { F.Wt. }\end{array}$ & $\begin{array}{c}\begin{array}{c}\text { Reducing } \\
\text { power } \\
\mu \mathrm{g} \mathrm{g}^{-1} \mathbf{F} . W t .\end{array} \\
\end{array}$ & $\begin{array}{l}\text { Total antioxidants } \\
\text { Abs. (at } 695 \mathrm{~nm} \mathrm{ml}^{-1} \text { ) }\end{array}$ & $\begin{array}{l}\text { Flavonoids } \\
\text { mg g }^{-1} \text { F.Wt. }\end{array}$ & $\begin{array}{c}\text { Lipid } \\
\text { peroxidation } \\
\text { Inhibition } \\
\%\end{array}$ & $\begin{array}{c}\mathrm{OH}^{-} \text {radical } \\
\text { scavenging } \\
\%\end{array}$ & $\begin{array}{c}\mathrm{H}_{2} \mathrm{O}_{2} \\
\text { radical } \\
\text { scavenging } \\
\%\end{array}$ & $\begin{array}{c}\text { Metal } \\
\text { Chelating } \\
\%\end{array}$ \\
\hline Control & Zero & $0.49 \pm 0.02^{\mathrm{c}}$ & $0.27 \pm 0.015^{\mathrm{g}}$ & $14.32 \pm 0.7^{\mathrm{a}}$ & $0.33 \pm 0.021^{\mathrm{d}}$ & $87.38 \pm 2.2^{\mathrm{c}}$ & $92.98 \pm 4.1^{\mathrm{b}}$ & $90.10 \pm 1.9^{b}$ & $92.29 \pm 4.2^{\mathrm{c}}$ \\
\hline \multirow{3}{*}{ Without Si } & 30 & $0.39 \pm 0.013^{b}$ & $0.14 \pm 0.013^{\mathrm{c}}$ & $14.31 \pm 0.6^{\mathrm{a}}$ & $0.27 \pm 0.022^{\mathrm{c}}$ & $94.74 \pm 5.1^{\mathrm{h}}$ & $96.03 \pm 2.2^{\mathrm{g}}$ & $96.02 \pm 1.4^{\mathrm{c}}$ & $94.17 \pm 3.5^{\mathrm{g}}$ \\
\hline & 60 & $0.92 \pm 0.02^{\mathrm{i}}$ & $0.21 \pm 0.012^{\mathrm{d}}$ & $45.10 \pm 0.7^{\mathrm{h}}$ & $0.46 \pm 0.011^{\mathrm{g}}$ & $88.72 \pm 1.1^{\mathrm{e}}$ & $94.50 \pm 1.4^{\mathrm{e}}$ & $98.94 \pm 2.5^{\mathrm{i}}$ & $92.57 \pm 3.4^{\mathrm{d}}$ \\
\hline & 90 & $0.82 \pm 0.03^{\mathrm{g}}$ & $0.23 \pm 0.011^{\mathrm{e}}$ & $39.08 \pm 0.9^{\mathrm{f}}$ & $0.39 \pm 0.010^{\mathrm{e}}$ & $86.87 \pm 2.4^{\mathrm{b}}$ & $93.05 \pm 0.9^{\mathrm{c}}$ & $98.74 \pm 3.1^{\mathrm{h}}$ & $91.93 \pm 1.5^{\mathrm{b}}$ \\
\hline \multirow{5}{*}{ With Si } & Zero $^{+S i}$ & $0.77 \pm 0.03^{\mathrm{f}}$ & $0.26 \pm 0.014^{\mathrm{f}}$ & $33.62 \pm 0.6^{\mathrm{e}}$ & $0.47 \pm 0.014^{\mathrm{h}}$ & $88.64 \pm 3.1^{\mathrm{d}}$ & $93.09 \pm 1.8^{\mathrm{d}}$ & $96.59 \pm 1.4^{\mathrm{d}}$ & $92.81 \pm 4.2^{\mathrm{f}}$ \\
\hline & $30^{+\mathrm{Si}}$ & $0.38 \pm 0.021^{\mathrm{a}}$ & $0.09 \pm 0.011^{\mathrm{a}}$ & $20.62 \pm 1.0^{\mathrm{b}}$ & $0.24 \pm 0.008^{\mathrm{b}}$ & $94.86 \pm 1.1^{\mathrm{i}}$ & $97.63 \pm 0.99^{\mathrm{i}}$ & $98.63 \pm 3.4^{\mathrm{g}}$ & $96.16 \pm 1.3^{\mathrm{i}}$ \\
\hline & $60^{+S i}$ & $0.61 \pm 0.01^{\mathrm{d}}$ & $0.11 \pm 0.012^{\mathrm{b}}$ & $30.24 \pm 1.5^{\mathrm{d}}$ & $0.27 \pm 0.011^{\mathrm{c}}$ & $94.21 \pm 2.1^{\mathrm{g}}$ & $97.15 \pm 3.1^{\mathrm{h}}$ & $98.23 \pm 2.1^{\mathrm{f}}$ & $95.44 \pm 0.9^{\mathrm{h}}$ \\
\hline & $90^{+\mathrm{Si}}$ & $0.84 \pm 0.0 .02^{\mathrm{h}}$ & $0.58 \pm 0.01^{\mathrm{h}}$ & $41.89 \pm 1.1^{\mathrm{g}}$ & $0.43 \pm 0.013^{\mathrm{f}}$ & $89.15 \pm 3.2^{f}$ & $95.06 \pm 2.9^{\mathrm{f}}$ & $97.50 \pm 1.1^{\mathrm{e}}$ & $92.58 \pm 2.1^{\mathrm{e}}$ \\
\hline & $120^{+\mathrm{Si}}$ & $0.70 \pm 0.01^{\mathrm{e}}$ & $1.65 \pm 0.01^{\mathrm{i}}$ & $25.93 \pm 1.9^{\mathrm{c}}$ & $0.09 \pm 0.009^{\mathrm{a}}$ & $60.60 \pm 4.3^{\mathrm{a}}$ & $84.24 \pm 3.2^{\mathrm{ga}}$ & $87.39 \pm 1.2^{\mathrm{a}}$ & $83.34 \pm 3.1^{\mathrm{a}}$ \\
\hline
\end{tabular}

Under elevated concentration of $\mathrm{NaCl}(30,60$ and 90 $\mathrm{mM}$ ) canola seedlings showed significant raise in $\mathrm{H}_{2} \mathrm{O}_{2}$ radical scavenging \% as compared to control (Table 2). Silicon application showed similar trend at 30 and 60 $\mathrm{mM} \mathrm{NaCl}$, while higher level of salinity $(90 \mathrm{mM})$ exhibited lower scavenging percent of $\mathrm{H}_{2} \mathrm{O}_{2}$ radical as compared to corresponding salinity level without silicon. Another reduction in $\mathrm{H}_{2} \mathrm{O}_{2}$ radical scavenging \% observed at $120 \mathrm{mM} \mathrm{NaCl}$ with $\mathrm{Si}$.

At sodium chloride concentrations (30 and $60 \mathrm{mM}$ ) a significant induction appeared at the chelating Percent of metals, however, higher concentration of $\mathrm{NaCl}(90$ $\mathrm{mM}$ ) reduced significantly the metal chelating \% (Table 2). On the other hand, external application of $\mathrm{Si}$ improved significantly the chelating percent of metals of canola seedling at (30, 60 and $90 \mathrm{mM}) \mathrm{NaCl}$ as compared to control or corresponding salinity concentration without Si. While a significant reduction at metal chelating $\%$ observed at $120 \mathrm{mM} \mathrm{NaCl}$ with Si.

Salinity resulted in reducing the activity of Lypoxygenase enzyme (LOX). Also individual application of $\mathrm{Si}$ resulted in a significant reduction in LOX activity without $\mathrm{NaCl}$ as compared to absolute control, then significant gradual increase in LOX activity was observed at $30,60,90$ and $120 \mathrm{mM} \mathrm{NaCl}$ with Si (Table 3).

Table 3 is representing the change in soluble proteins. As compared to control, a significant reduction was observed under $30 \mathrm{mM} \mathrm{NaCl}$, while high levels (60 and $90 \mathrm{mM}$ ) exhibited a significant increase in soluble proteins. In contrast, external amendment with $\mathrm{Si}$ caused significant reduction in soluble proteins content at almost all salinity levels. While the individual significant induction in soluble proteins observed with silicon treatment was at $120 \mathrm{mM} \mathrm{NaCl}$, as compared to control.
It was recorded a decrease in enzymatic activity SOD and POD whether we added salinity individually or with silicon (Table 3). On the other hand, a significant increase of SOD activity at (60 and $90 \mathrm{mM} \mathrm{NaCl})$ with silicon amendment could be observed as compared to corresponding salinity levels without $\mathrm{Si}$. Another significant induction could be observed of SOD and POD at $120 \mathrm{mM} \mathrm{NaCl}$ with Si. It was also observed that the application of silicon without salinity had a positive effect on the activity of both enzymes if compared to the control. Catalase enzyme (CAT) showed slight induction at $(30 \mathrm{mM} \mathrm{NaCl})$ or showed no change at $(90$ $\mathrm{mM} \mathrm{NaCl}$ ), except at $60 \mathrm{mM} \mathrm{NaCl}$ a significant reduction was observed (Table 3). Exogenous $\mathrm{Si}$ application reduced the activity of CAT under 0 and 30 $\mathrm{mM} \mathrm{NaCl}$, while significant increases in CAT activity were observed under 60 and 90 when compared to corresponding salinity levels. Si external application induced greatly CAT $120 \mathrm{mM} \mathrm{NaCl}$. Ascorbate peroxidase enzyme (APX) activity is shown in Table 3. General reduction in the APX activity was observed at different concentration of $\mathrm{NaCl}$ with or without $\mathrm{Si}$ application, but obvious significant rise was occurred at $120 \mathrm{mM} \mathrm{NaCl}$ with $\mathrm{Si}$.

\section{DISCUSSION}

Soil salinity influences negatively growth and productivity of crop plants. In the Middle East $20 \times 10^{6}$ ha area is affected by increased groundwater and soil salinity, reasons being irrigation practices, high evaporation rates, growth of sabkhas (salt scalds), and increase in groundwater salinity. In Egypt $1 \times 10^{6}$ ha cultivable land along the Nile is salt-affected (Shahid, 2013). Canola is very promising oil crop cultivated in Egypt. 
Table (3): Soluble proteins content,lipoxygenase (LOX) and some enzymatic antioxidants of canola (Brassica napus L. cultivar Sarw 4) as influenced by $\mathrm{NaCl}(\mathrm{mM})$ stress and silicon $\left(1 \mathrm{mM} \mathrm{Na}_{2} \mathrm{SiO}_{3}\right)$, different letters are significantly different at $\mathrm{p}<0.05$, (mean \pm SE; $n=3$ ).

\begin{tabular}{|c|c|c|c|c|c|c|c|}
\hline \multicolumn{2}{|c|}{$\begin{array}{c}\text { NaClConc. } \\
\text { mM }\end{array}$} & \multirow{2}{*}{$\begin{array}{c}\begin{array}{c}\text { LOX } \\
\text { min } \text { mg }^{-1} \\
\text { proteins }\end{array} \\
2.44 \pm 0.10^{\mathrm{f}}\end{array}$} & \multirow{2}{*}{$\begin{array}{c}\begin{array}{c}\text { SOD } \\
\text { unit mg-1 } \\
\text { proteins }\end{array} \\
16.0 \pm 0.5^{\mathrm{h}}\end{array}$} & \multirow{2}{*}{$\begin{array}{c}\begin{array}{c}\text { POD } \\
\text { min } \text { mg }^{-1} \\
\text { proteins }\end{array} \\
0.10 \pm 0.004^{\mathrm{h}}\end{array}$} & \multirow{2}{*}{$\begin{array}{c}\text { CAT } \\
\text { min } \text { mg }^{-1} \\
\text { proteins }\end{array}$} & \multirow{2}{*}{$\begin{array}{c}\begin{array}{c}\text { APX } \\
\text { min } \text { mg }^{-1} \\
\text { proteins }\end{array} \\
0.10 \pm 0.002^{\mathrm{e}}\end{array}$} & \multirow{2}{*}{$\begin{array}{c}\begin{array}{c}\text { Soluble } \\
\text { Proteins } \\
\mathbf{m g ~ g}^{-1} \mathbf{~ F}\end{array} \\
30.0 \pm 0.5^{\mathrm{e}}\end{array}$} \\
\hline Control & Zero & & & & & & \\
\hline \multirow{3}{*}{ Without Si } & 30 & $1.02 \pm 0.11^{\mathrm{b}}$ & $10.9 \pm 0.9^{\mathrm{g}}$ & $0.09 \pm 0.001^{\mathrm{g}}$ & $0.11 \pm 0.006^{\mathrm{e}}$ & $0.07 \pm 0.003^{\mathrm{d}}$ & $18.5 \pm 1.1^{\mathrm{c}}$ \\
\hline & 60 & $1.31 \pm 0.12^{\mathrm{d}}$ & $7.2 \pm 0.8^{\mathrm{a}}$ & $0.06 \pm 0.001^{\mathrm{d}}$ & $0.06 \pm 0.003^{\mathrm{a}}$ & $0.04 \pm 0.002^{\mathrm{a}}$ & $38.8 \pm 0.7^{\mathrm{i}}$ \\
\hline & 90 & $0.99 \pm 0.11^{\mathrm{a}}$ & $8.3 \pm 0.2^{c}$ & $0.08 \pm 0.005^{\mathrm{f}}$ & $0.10 \pm 0.009^{\mathrm{d}}$ & $0.10 \pm 0.006^{\mathrm{e}}$ & $34.5 \pm 2.0^{\mathrm{f}}$ \\
\hline \multirow{5}{*}{ 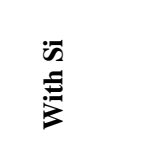 } & Zero $^{+\mathrm{Si}}$ & $1.17 \pm 0.10^{\mathrm{c}}$ & $10.1 \pm 0.3^{\mathrm{f}}$ & $0.06 \pm 0.003^{\mathrm{c}}$ & $0.08 \pm 0.004^{\mathrm{c}}$ & $0.05 \pm 0.003^{b}$ & $38.4 \pm 1.0^{\mathrm{h}}$ \\
\hline & $30^{+\mathrm{Si}}$ & $2.29 \pm 0.15^{\mathrm{e}}$ & $7.9 \pm 0.2^{\mathrm{b}}$ & $0.07 \pm 0.003^{\mathrm{e}}$ & $0.07 \pm 0.003^{\mathrm{b}}$ & $0.06 \pm 0.002^{c}$ & $14.0 \pm 0.9^{\mathrm{a}}$ \\
\hline & $60^{+\mathrm{Si}}$ & $2.54 \pm 0.09^{g}$ & $8.8 \pm 0.2^{\mathrm{d}}$ & $0.05 \pm 0.003^{\mathrm{a}}$ & $0.12 \pm 0.006^{\mathrm{f}}$ & $0.06 \pm 0.004^{\mathrm{c}}$ & $15.9 \pm 1.1^{\mathrm{b}}$ \\
\hline & $90^{+\mathrm{Si}}$ & $4.63 \pm 0.10^{\mathrm{i}}$ & $9.9 \pm 0.3^{\mathrm{e}}$ & $0.06 \pm 0.003^{b}$ & $0.08 \pm 0.002^{c}$ & $0.05 \pm 0.001^{\mathrm{b}}$ & $26.1 \pm 1.3^{\mathrm{d}}$ \\
\hline & $120^{+\mathrm{Si}}$ & $4.29 \pm 0.11^{\mathrm{h}}$ & $28.1 \pm 0.4^{\mathrm{i}}$ & $0.14 \pm 0.005^{\mathrm{i}}$ & $0.22 \pm 0.002^{\mathrm{g}}$ & $0.14 \pm 0.007^{\mathrm{f}}$ & $34.6 \pm 1.6^{\mathrm{g}}$ \\
\hline
\end{tabular}

One of the approaches to improve growth and productivity of crop plants under soil salinity is the fertilizer treatments, which are capable to withstand unfavorable environmental conditions. To resist or avoid stress conditions, plants have evolved complex mechanisms to counter $\mathrm{NaCl}$ toxicity in soil caused by salinity (Munns and Tester, 2008). Recently, it was reported that exogenous application of $\mathrm{Si}$ contributed to the growth of strawberry plants by modulating ion homeostasis and antioxidant defense system (Ouellette et al., 2017, Yaghubi et al., 2016). Our study clearly showed that exogenous $\mathrm{Si}$ application improved salt tolerance in canola seedlings. Something was obvious as external application of silicon sustained the survival of canola seedling under $120 \mathrm{mM} \mathrm{NaCl}$. Seed germination and seedling establishment under high salt concentrations is very desirable response. The physiological responses implied that $\mathrm{Si}$ could modify the pace of physiological metabolisms and modulate the complex pathways of regulation under salt stress conditions. In this experiment, it has been shown that salt stress in canola caused very significant reductions in fresh weight. Our biomass data are in agreement with the work of Bar-Tal et al. (1991) for corn, and Kaya et al. (2001) for tomato. Inhibitory effect of salinity on plant growth may either be due to high ions $\left(\mathrm{Na}^{+}\right.$and $\left.\mathrm{Cl}^{-}\right)$ accumulation in plant tissues or to osmotic reduction in water availability (Gunes et al., 1995).

In the present study gradual raise in dry matter observed at elevated levels of salinity stress even at 90 $\mathrm{mM} \mathrm{NaCl}$. According to Abdul Qados (2011) the application of salinity at 60 and $120 \mathrm{mM} \mathrm{NaCl}$ in bean plant (Vicia faba L.) enhanced dry weight. Also, findings by Dantus et al. (2005) on cowpea (Vigna unguiculata L.), and Nedjimi et al. (2006), on (Atriplex halimus L.) agreed with the results of our study, they reported that with increasing concentrations of sodium chloride, dry weights of their seedlings increased.

On the other hand, there are findings, as well, representing the negative effect of salinity on dry matter. Such as a study on radish plants Raphanus sativus L by Jamil et al. (2007), another study on Bruguiera gymnorrhiza L., by Rui et al. (2009).

Salinity significantly suppressed shoot height and root length of canola, however root tissues received more stress than shoots (Table 1). Similar results were also reported on sugarcane, wheat and purslane (Kafi and Rahimi 2011; Ashraf et al. 2010; Tahir et al. 2010). It might be due to the direct contact of root tips with stress. Plant growth requires both proliferation and elongation of cells; so, growth reduction due to salinity stress may be attributed to osmotic stress, ion imbalance and ion toxicity (Marschner, 1995; Tahir et al., 2006; Yazici et al., 2007), that resulted in loosing the turgor and DNA synthesis for cell growth.

Supplementary silicon greatly improved plant growth and enhanced significantly the dry matter, Plant height, and root length of plants grown under salinity conditions. Similar results were observed in rice, cucumber, tomato and barley (Bonilla and Tsuchiya, 1998; Miyake, 1992; Liang, 1999). Ample evidences suggesting that $\mathrm{Si}$ plays very favorable role in plant growth under biotic and abiotic stresses. For instance, Tahir et al. (2010) found that silicon application significantly increased salt-treated plant biomass. External application of $\mathrm{Si}$ to salinity stressed plants has ameliorative effect through enhancing $\mathrm{K}^{+} / \mathrm{Na}^{+}$ratio (Kafi and Rahimi, 2011), improving quenching capacity of ROS (Hasanuzzaman et al., 2013) and protecting the cell membrane against lipid peroxidation. Liang et al. (1996) reported that external application of silicon accompanied with high salinity levels enhanced the growth of barley. He attributed this response to reduced electrolyte leakage in the leaves. Zhu et al. (2004) suggested that Si may decrease the plasma membranes permeability and retarded the peroxidation of membrane lipids besides maintaining the membrane integrity and functions of salt-stressed cucumber, thus mitigating against salt toxicity and improving the growth of plants. $\mathrm{Si}$ supplementation helps the formation of secondary and tertiary cells of the endodermis, thus enabling higher root resistance and a stronger growth of roots (Munns and Tester, 2008).

Crop growth could be related to rate of photosynthesis which is directly proportional to chlorophyll contents in leaves. The change in Chlorophylls content is a sensitive indicator of the cellular metabolic state especially under stresses; the reduction in its content is a commonly reported phenomenon under salinity (Chutipaijit et al., 2011). According to our results, salinity reduced $\mathrm{Chl}$ a contents; however, external application of $\mathrm{Si}$ to these plants buffered and improved the adverse 
effect of salinity on chl. a pigments. In the contrast, no mitigation impact of $\mathrm{Si}$ was found on chl.b (Table 3). Inhibition of chlorophyll biosynthesis (Haghighi and Pessarakli, 2013), acceleration of its degradation (Jamali et al., 2015) and oxidative damage induced by salinity (Munns and Tester, 2008) could be considered as main reasons for the declining the chlorophylls content. The present data of chlorophyll are also in agreement with the work of Yeo et al. (1990) on rice and that of Belkhodja et al. (1994) on barley, both showed the adverse effect of high $\mathrm{NaCl}$ on leaf chlorophyll concentrations.

In the present study silicon nutrition can recover the chlorophyll a content of canola plants under salinity. Previous studies have pointed to the positive effect of silicon to improve the chlorophyll content of canola and barley under salt stress (Liang et al., 1996; Kafi and Rahimi, 2010). This was interpreted as possible influence of silicon on the biosynthesis of new chlorophylls and the protection of existing chlorophylls against salinity-induced oxidative stress (Shekari et al., 2015). Our data reviled negative impact of salinity stress on carotenoids particularly at elevated concentration of salinity (Table 1). Mane et al. (2011) reported that, carotenoids can preserve its function as accessory pigments at low levels of salt concentration, but these molecules are inhibited and unable to protect chloroplast from photo-oxidative damage at higher levels. The inhibitory effect of Salinity over carotenoid content has been previously reported in maize and wheat genotypes (Singh et al., 2008; Sairam et al., 2002). The data obtained in this study, showed clearly a pronounced increase in the carotenoid content when Si incorporated with salt treatments. Mane et al. (2011) also reported that carotenoids can protect plants against oxidative stress. They are one of the non-enzymatic antioxidants along with vitamin $\mathrm{C}$, vitamin $\mathrm{E}$ and lipoic acid.

In the current study, the determination of lipid peroxidation inhibition $\%$, hydroxyl radical scavenging $\%, \mathrm{H}_{2} \mathrm{O}_{2}$ radical scavenging $\%$ and metal chelating $\%$ were used to evaluate the ability of the antioxidant system of the stressed cell to protect its different compartments and membranous system from peroxidation and deterioration under salinity stress, in addition to evaluate the protective action of silicon. Our data showed that incorporation of $\mathrm{Si}$ into salt-treatment increased lipid peroxidation inhibition \% compared with the treatment of salt alone (Table 2). In previous study, it was reported that $\mathrm{Si}$ enhanced the stability of lipids in cell membranes of rice plants exposed to drought and heat stresses, suggesting that Si prevented the structural and functional deterioration of cell membranes when rice plants were exposed to environmental stress (Agarie et al., 1998).

Hostile environments such as salinity impairs cellular electron transport within the different subcellular compartments and leads to generation of reactive oxygen species (ROS) such as hydrogen peroxide, superoxide, hydroxyl radical and singlet oxygen (Lee et al., 2001), which triggers phytotoxic reactions such as lipid peroxidation and membrane damage (Parihar et al., 2015). Results presented in table (2) showed that external application of silicon obviously enhanced the ability of canola cells to scavenge the hydroxyl free radical and metal chelating as compared with seedling subjected to salinity without silicon.

Loading plot of different studied attributes correlations to the first two Principle component analysis (PCA) axes (Fig. 1) and Cluster analysis (Fig. 2) emphasized a strong positive correlation among the scavenging percent of hydroxyl, metal chelating $\%$ and lipid peroxidation inhibition. This findings implying to the protective effect of silicon against ROS generation under salinity stress which had a strong stabilizing effect on membranes function and integrity, thus our data suggests that $\mathrm{Si}$ application could maintain the permeability of plasma membranes and sustain the membrane integrity and functions of canola plant under salinity, mitigating against oxidative burst and salt toxicity. Something reflected in the final improvement of seedling growth.

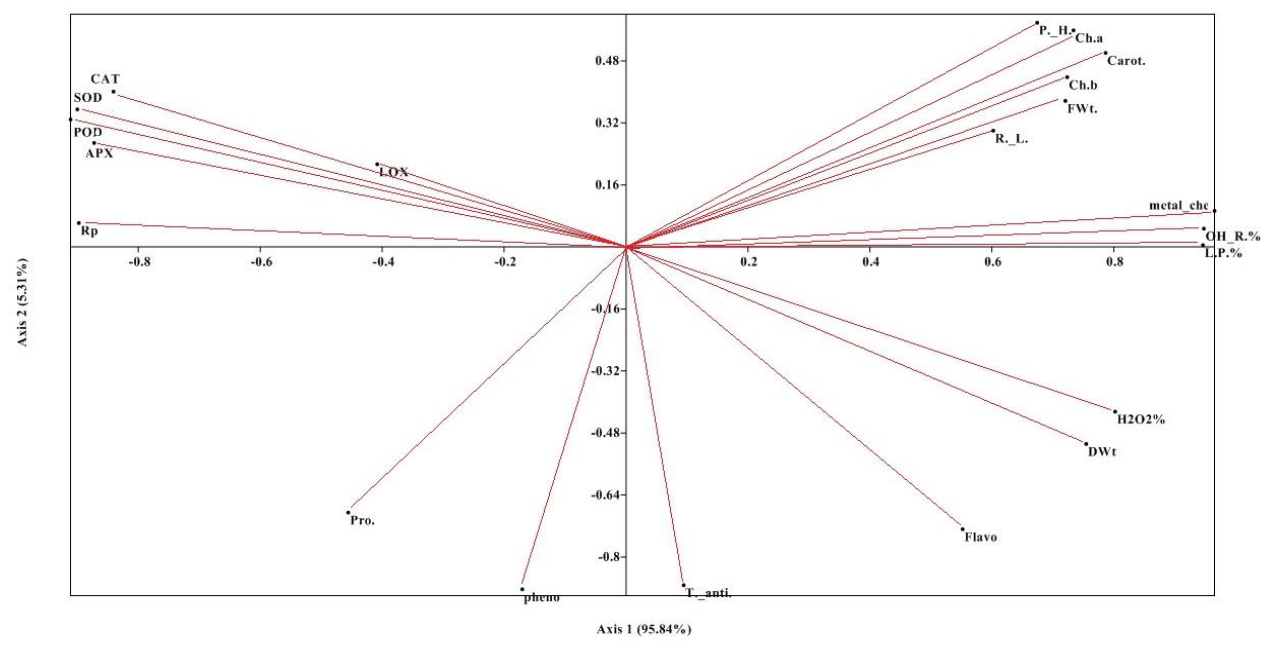

Figure (1): Loading plot of different studied attributes correlations to the first two Principle component analysis $(\mathrm{PCA})$ axes. Abbreviations: Pheno $=$ Total Phenolics, T-anti $=$ Total Antioxidants, Pro $=$ Proteins, Flavo. $=$ Total Flavonoids, Rp $=$ Reducing Power, LOX $=$ Lipoxygenase, POD = Peroxidase, $\mathrm{SOD}=$ Superoxide Dismutase, $\mathrm{CAT}=$ Catalase, $\mathrm{APX}=$ Ascorbate peroxidase, Ch. $\mathrm{a}=\mathrm{Chlorophyll} \mathrm{a}, \mathrm{Ch} . \mathrm{b}=\mathrm{Chlorophyll} \mathrm{b}, \mathrm{Carot} .=$ Carotenoids, $\mathrm{LP} \%=$ Lipid peroxidation inhibition $\%, \mathrm{OH}-\mathrm{R}=\mathrm{Hydroxyl}$ radical scavenging $\%, \mathrm{MC}=\mathrm{Metal}$ chelating $\%, \mathrm{H}_{2} \mathrm{O}_{2} \%=\mathrm{Hydrogen}$ peroxide scavenging $\%$, R.L $=$ Root length, P.H. = Shoot height, DWt $=$ Dry weight, FWt $=$ Fresh weight. 


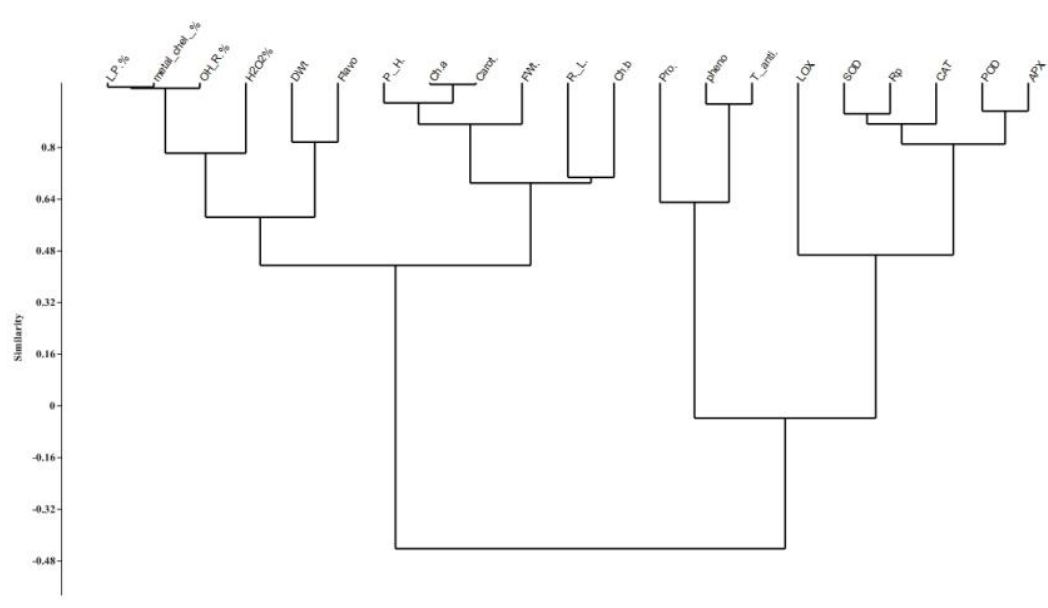

Figure (2): Cluster analysis of measured attributes show significance.

The balance in the steady-state level of superoxide radicals and hydrogen peroxide, together with sequestering of metal ions, is thought to be important to prevent the formation of the highly toxic hydroxyl radical via the metal-dependent Haber-Weiss or the Fenton reactions (Asada and Takahashi, 1987). Timely induction of cellular antioxidant machinery is considered as a vital approach for protection against various abiotic stresses via scavenging or detoxifying the ROS generated therein (Khare et al., 2015).

In the present study, salinity induced the content of phenolics in seedlings of canola significantly with or without Si. Navarro et al. 2006 showed similar results, he reported an enhancement in total phenolic contents at moderate saline levels in red peppers (Capsicum аппиит). Phenolic compounds can act as antioxidant to scavenge ROS in plants under stresses (Solecka, 1997). The present data indicated that moderate and high salinity concentrations enhanced flavonoid without $\mathrm{Si}$ (Table 2). This may be due to enzymatic activity inductions occurring under salinity condition and resulting in synthesis of different flavonoid compounds (Haghighi et al., 2012). It has been found that there is considerable increase in flavonoid levels following biotic and abiotic stresses, such as wounding, drought, metal toxicity and nutrient deprivation (Winkel-Shirley, 2002). Flavonoids and other phenolics, these secondary metabolites play multiple roles in plants, including scavenging of ROS induced under different stress, they promote roles in plant protection against damaging effects (Sonar et al., 2011).

The measurement of reducing power of a compound may serve as a significant indicator of its potential antioxidant activity. An obvious increase in reducing power assay was observed when $\mathrm{Si}$ incorporated at $(90$ and $120 \mathrm{mM} \mathrm{NaCl}$ ), while a significant induction was observed when salinity applied alone at $(30$ and $60 \mathrm{mM}$ $\mathrm{NaCl}$ ). The results showed that $\mathrm{Si}$ application can improve the redox status of canola under high salinity levels.

On the other hand, salt stress incorporated with $\mathrm{Si}$ significantly increased the total antioxidants content of canola seedlings, which increased with increasing the salinity levels. In the present work, PCA and cluster analysis showed positive correlation between total antioxidants and phenol contents. Statistical evaluation by pearson correlation between total antioxidants and total phenolic contents (Table 4) was found to be highly significant $\left(\mathrm{r}=935^{* *}\right)$. On the other hand, correlation between the total antioxidants and reducing power was found to be non-significant $(r=0.023)$. Another nonsignificant correlation was observed between reducing power content and the total phenolic contents ( $\mathrm{r}=$ 0.23 ). This indicates that phenolic compounds might be a major contributor to the antioxidant capacities under salinity stress.

It has been reported by many researchers the positive correlation between the total phenolic content and antioxidant activity (Chew et al., 2008 and Wang et al., 2009). Djeridane et al. (2006) reported synergistic interactions in a mixture of phenolic and interactions between the antioxidants. It has been proven that the antioxidant activity of plant extracts is mainly ascribable to concentration of phenolic compounds in plant (Heim et al., 2002). Based on these results (Gressel and Galun, 1994) showed that adaptation to ionic and osmotic stresses caused by salinity need complex mechanisms evolved by plants. The capacity of the antioxidant defense system to increase under stress conditions may be associated with salt tolerance (Abogadallah, 2010). Increased LOX activity, presented in this work under salinity stress with $\mathrm{Si}$ compared to salinity without Si treatments suggests higher lipolytic activity of the membranes and oxidation of membrane-bound fatty acids, which propagates higher lipid peroxidation (Tavallali et al., 2010). On the other hands, the previous data of lipid peroxidation inhibition $\%$ shows higher level of membranes protection under Si treatment. This could be attributed to the biosynthesis of enzymatic and non-enzymatic antioxidants to protect membranens. SOD, CAT, APX and POS are the major antioxidant enzymes associated with scavenging the ROS (Marschner, 1995). In this study, SOD and POD activities were decreased by adding the $\mathrm{NaCl}$ to nutrient medium (Table 3). On the other hand, external application of Si improves the activity of SOD at 60 and $90 \mathrm{mM} \mathrm{NaCl}$. 


\section{Ameliorating Effect of Silicon on Growth Vigor, Physiological and biochemical}

Among ROSs, $\mathrm{H}_{2} \mathrm{O}_{2}$ is a functional element, which is produced by activity of superoxide dismutase (Eraslan et al., 2008). High ratios of hydrogen peroxide as well as malondealdehyde under salinity are responsible for membrane deterioration (Gupta and Huang, 2014). Mitigation role of Si on salt-induced cell damage is well documented (Eraslan et al., 2008; Haghighi and Pessarakli, 2013). Shekari et al. (2015) revealed that application of Si to salt-subjected plants decreased significantly the content of MDA and $\mathrm{H}_{2} \mathrm{O}_{2}$. Our results give supporting information that cellular damage induced by $\mathrm{NaCl}$ is alleviated by $\mathrm{Si}$, as represented by higher lipid peroxidation inhibition $\%$ as well as higher hydroxyl radicle scavenging $\%$.

Silicon application enhanced the activity of CAT and APX at $60 \mathrm{mM} \mathrm{NaCl}$ as compared to corresponding salinity level without $\mathrm{Si}$. In addition to these findings, work showed that CAT and APX activities even got higher at $120 \mathrm{mM} \mathrm{NaCl}$. Gosset et al. (1994) reported that in cotton, $\mathrm{NaCl}$ decreases the activity of APX. Results further highlighted that external application of $\mathrm{Si}$ with increasing salt concentrations, resulted in escalation in CAT and APX activities, which indicating their crucial role in scavenging $\mathrm{O}_{2}{ }^{-}$during salt stress.

The present study showed higher protein concent-rations in salt stressed seedling without Si than in salt stress seedling with $\mathrm{Si}$ (Table 3). To survive under stress, plants accumulate proteins that protect cells from stress effects (Wang et al., 2003). Protein contents in Vignia unguiculata (L) were not affected compared to controls, while it significantly increased in the stems of plants grown with $100 \mathrm{mM}$ of sodium chloride (Franco et al., 1999). This could be a consequence of salinity stress on protein synthesis as previously reported by (Omar et al., 1993). Salinity stress which frequently leads to oxidative stress may cause denaturing of structural and functional proteins (Shanker et al., 2004; Mandhania et al., 2006). The diverse environmental stresses often promote similar cell signaling pathways (Foyer et al., 1994) and cellular responses, such as the production of stress proteins and up regulation of antioxidants (Zhu et al., 1997).

Table 4: Correlation coefficient values ( $\mathrm{r} 2$ ) among different parameters of canola (Brassica napus L. cultivar Sarw 4) as influenced by $\mathrm{NaCl}_{(\mathrm{mM})}$ stress and silicon (1 $\mathrm{mM} \mathrm{Na} 2 \mathrm{SiO}_{3}$ ).

\begin{tabular}{|c|c|c|c|c|c|c|c|c|c|c|c|c|c|c|c|c|c|c|c|c|}
\hline & F.Wt. & D.Wt. & Shoot H. & Root L. & $\begin{array}{l}\text { Ch.a } \\
\end{array}$ & $\begin{array}{l}\text { Ch.b } \\
\end{array}$ & Carot & LOX & SOD & POD & CAT & APX & Pro & pheno & $\mathrm{Rp}$ & T-anti & Flavo. & LP \% & OH'R. \% & $\overline{\mathrm{H}_{2} \mathrm{O}_{2} \%}$ \\
\hline D.Wt. & $\begin{array}{c}0.547 \\
871 * *\end{array}$ & & & & & & & & & & & & & & & & & & & \\
\hline $\begin{array}{l}\text { shoot } \mathrm{H} \text {. } \\
\text { Root L. }\end{array}$ & $\begin{array}{l}.871^{* *} \\
0.58\end{array}$ & $\begin{array}{l}0.274 \\
0.439\end{array}$ & $.704 *$ & & & & & & & & & & & & & & & & & \\
\hline $\begin{array}{l}\text { Root L. } \\
\text { Ch.a }\end{array}$ & $\begin{array}{l}0.58 \\
.864^{* * *}\end{array}$ & 0.345 & $.947 * *$ & $.756^{*}$ & & & & & & & & & & & & & & & & \\
\hline Ch.b & 0.521 & 0.224 & $.753 *$ & $.708^{*}$ & $.730 *$ & & & & & & & & & & & & & & & \\
\hline Carot & $.881 * *$ & 0.417 & $.929 * *$ & $.749 *$ & $.995 * *$ & $.725^{*}$ & & & & & & & & & & & & & & \\
\hline LOX & 0.193 & -0.107 & -0.079 & -0.025 & -0.047 & -0.406 & -0.064 & & & & & & & & & & & & & \\
\hline SOD & -0.421 & $-.785^{*}$ & -0.318 & -0.33 & -0.372 & -0.548 & -0.446 & 0.556 & & & & & & & & & & & & \\
\hline POD & -0.645 & $-.902 * *$ & -0.492 & -0.47 & -0.534 & -0.524 & -0.597 & 0.318 & $.91 * *$ & & & & & & & & & & & \\
\hline CAT & -0.39 & $-.793^{*}$ & -0.274 & -0.431 & -0.391 & -0.401 & -0.465 & 0.473 & $.90 * *$ & $.81 * *$ & & & & & & & & & & \\
\hline APX & -0.572 & $-.898 * *$ & -0.403 & -0.48 & -0.546 & -0.388 & -0.614 & 0.301 & $.84 * *$ & $.91 * *$ & $.84 * *$ & & & & & & & & & \\
\hline Pro & -0.566 & -0.018 & -0.539 & -0.257 & -0.584 & -0.589 & -0.592 & -0.118 & 0.25 & 0.21 & 0.08 & 0.20 & & & & & & & & \\
\hline pheno & -0.239 & 0.414 & -0.46 & -0.232 & -0.49 & -0.493 & -0.46 & 0.101 & -0.08 & -0.23 & -0.09 & -0.15 & $.75^{*}$ & & & & & & & \\
\hline Rp & -0.468 & -0.55 & -0.5 & -0.332 & -0.523 & -0.651 & -0.576 & $.688 *$ & $.90 * *$ & $.77 *$ & $.84 * *$ & $.70^{*}$ & 0.35 & 0.232 & & & & & & \\
\hline T-anti & -0.078 & 0.611 & -0.343 & -0.083 & -0.329 & -0.255 & -0.28 & 0.054 & -.35 & -.48 & -.29 & -.38 & 0.51 & $.935^{* *}$ & 0.023 & & & & & \\
\hline Flavo. & 0.208 & $.816^{* * *}$ & 0.044 & 0.199 & 0.055 & 0.006 & 0.12 & -0.401 & $-.69^{*}$ & $-.71^{*}$ & $-.80^{* *}$ & $-.69^{*}$ & 0.42 & 0.561 & -0.564 & 0.608 & & & & \\
\hline LP\% & 0.606 & 0.646 & 0.549 & 0.384 & 0.598 & 0.637 & 0.659 & -0.513 & $-.90 * *$ & $-.81^{* *}$ & $-.84 * *$ & $-.78^{*}$ & -0.51 & -0.283 & $-.960 * *$ & -0.036 & 0.519 & & & \\
\hline OH'R. \% & 0.649 & 0.65 & 0.551 & 0.395 & 0.629 & 0.657 & $.692 *$ & -0.395 & $-.89 * *$ & $-.82^{* *}$ & $-.80^{* *}$ & $-.79^{*}$ & -0.61 & -0.294 & $-.911 * *$ & -0.007 & 0.428 & $.980 * *$ & & \\
\hline $\mathbf{H}_{2} \mathbf{O}_{2} \%$ & 0.322 & $.778 *$ & 0.193 & 0.287 & 0.252 & 0.516 & 0.324 & -0.461 & $-.95^{* *}$ & $-.89^{* *}$ & $-.77 *$ & $-.80^{* *}$ & -0.25 & 0.2 & $-.749 *$ & 0.498 & 0.597 & $.775^{*}$ & $.801 * *$ & \\
\hline m. ch.\% & 0.65 & 0.614 & 0.623 & 0.473 & $.678^{*}$ & $.735^{*}$ & $.732 *$ & -0.474 & $-.89^{* *}$ & $-.81^{* *}$ & $-.81 * *$ & $-.77^{*}$ & -0.57 & -0.334 & $-.948 * *$ & -0.065 & 0.441 & $.987 * *$ & $.986 * *$ & $.771 *$ \\
\hline
\end{tabular}

*. Correlation is significant at the 0.05 level (2-tailed). 


\section{CONCLUSION}

In conclusion, silicon had ameliorative effects on canola germination, growth, chlorophyll a, and antioxidant parameters under salinity. This can provide a basis for attempting new strategies for diminishing the salinity damages and establishing a functional link between silicon function, morphophysiological response and salt stress tolerance in canola plants. Our results showed that the higher reactive oxygen species scavenging capacities induced in canola seedlings by $\mathrm{Si}$ application and this ability was associated with the higher level of lipid peroxidation inhibition $\%$, reducing power and carotenoids contents. These data suggest silicon can improve the redox status of canola cells. This agricultural practice is recommended for saline soils.

\section{REFERENCES}

ABDUL QADOS, A.M.S. 2011. Effect of Salt Stress on Plant Growth and Metabolism of Bean Plant Vicia faba (L.), J. Saudi Soc. Agri. Sci., 10: 7-15.

ABIDEEN, Z., H.W. KOYRO, B. HUCHZERMEYER, M.Z. AHMED, B. GUL, AND M.A. KHAN. 2014 Moderate salinity stimulates growth and photosynthesis of Phragmites karka by water relations and tissue specific ion regulation, Environ Exp Bot., 105: 70-6.

ABOGADALLAH, M.G. 2010. Antioxidative defense under salt stress, Plant Signal Behav., 5: 369-374.

AEBI, H. 1984. Catalase. In Methods in Enzymology (ed. 1. paker) Vol. 105: 121-126. Academic press, Orlando, Fl., USA.

AGARIE, S., N. HANAOKA, O. UENO, A. MIYAZAKI, F. KUBOTA, W. AGATA AND P.B. KAUFMAN. 1998. Effects of Silicon on Tolerance to Water Deficit and Heat Stress in Rice Plants (Oryza sativa L.) Monitored by Electrolyte Leakage, Plant Prod. Sci., 96-103.

ASADA, K., AND M.TAKAHASHI. 1987. Production and Scavenging of Active Oxygen in Photosynthesis, In Photoinhibition (Kyle, D.J. et al., eds), pp. 227-287, Elsevier

ASHRAF, M., AND T. MCNEILLY. 2004. Salinity Tolerance in Brassica Oilseeds, Crit Rev Plant Sci., 23: $157-74$

ASHRAF, R., R. AHMAD, A.S. BHATTI, M. AFZAL, A. SARWAR, M.A. MAQSOOD, AND S. KANWAL. 2010. Amelioration of Salt Stress in Sugarcane (Saccharum officinarum L.) by Supplying Potassium and Silicon in Hydroponics, Pedosphere, 20: 153-162.

BAR-TAL, A., S. FERGENBAUN, AND D.L. SPARKS. 1991. Potassium-salinity interaction in irrigated corn, Irr. Sci., 12: 27-35.

BEAUCHAMP, B.C., AND FEDOVICH. 1976. Superoxide Dismutase Assay and An Assay Applicable to Acrylamide Gel, Anal. Biochem., 10: 276287.

BELKHODJA, R., F. MORALES, A. ABADIA, J. GOMEZ-APARISI, AND J. ABADIA. 1994. Chlorophyll fluorescence as a possible tool for salinity tolerance screening in barley (Hordeum vulgare L.), Plant Physiol., 104: 667-673.

BONILLA, P.S., AND M. TSUCHIYA. 1998. Induction of salt tolerance in rice by silica treatment, Philip. J. Crop Sci., 23: 35-44.

BROADLEY, M., P. BROWN, I. CAKMAK, J.F. MA, Z. RENGEL AND F. ZHAO. 2002. Benifitical elements. In: Marschner, P. (Ed.), Marschner's Mineral Nutrition of Higher Plants, thirded. Academic Press, San Diego, USA, pp. 249-269.

CHEW, Y.L., Y.Y. LIM, M. OMAR, AND K.S. KHOO. 2008. Antioxidant Activity of Three Edible Seaweeds from Two Areas in South East Asia, LWT., 41, 1067-1072.

CHUTIPAIJIT, S., S.CHA-UM, AND K. SOMPORNPAILIN. 2011. High Contents of Proline and Anthocyanin Increase Protective Response to Salinity in Oryza Sativa L. spp. Indica, Aust. J. Crop Sci., 5: 1191-1198.

DANTUS, B.F., L. RIBEIRO, AND C.A. ARAGAO. 2005. Physiological Response of Cowpea Seeds to Salinity Stress, Rev. Bras. Sementes., 27: 144-148.

DECKER, W., AND BARBARA. 1990. Role of Ferritin as A Lipid Oxidation Catalyst in Muscle, food. J. of Agric. and Food Chem., 38: 674-677.

DJERIDANE, M., B. YOUSFI, D. NADJEMI, P. BOUTASSOUNA, AND N. STOCKER. 2006. Antioxidant Activity of some Algerian Medicinal Plants Extracts Containing Phenolic Compounds. Food Chem., 97: 654-660.

ERASLAN, F., A. INAL, D.J. PILBEAM, AND A. GUNES. 2008. Interactive Effects of Salicylic Acidand Silicon on Oxidative Damage and Antioxidant Activity in Spinach (Spinaciaoleracea L. cv. Matador) Grown under Boron Toxicity and Salinity, Plant Growth Regul., 55: 207-219.

FOYER, C.H., M. LELANDAIS, AND K.J. KUNERT. 1994. Photooxidative Stress in Plants, Physiol. Plant, 92: 696-717.

FRANCO, O.L., J.E. FILHO, J.T. PRISCO AND E.G. FILHO. 1999. Effects of $\mathrm{CaCl}_{2}$ on Growth and Osmoregulator Accumulation in $\mathrm{NaCl}$ Stressed Cowpea Seedlings, Revista Brasileira de Fisiología Vegetal, 11(3): 145-151.

GOSSETT, D.R., E.P. MILLHOLLON, AND M.C. LUCAS. 1994. Antioxidant response to $\mathrm{NaCl}$ stress in salt tolerant and salt sensitive cultivars of cotton, Crop Science, 34: 706-714.

GRESSEL, J., AND E. GALUN. 1994. Genetic Controls of Photooxidant Tolerance. In: Foyer $\mathrm{CH}$, Mullineaux PM (eds) Causes of photooxidative Stress and Amelioration of Defense Systems in plant, CRC Press, Boca Raton, pp 237-274.

GUNES, A., A. INAL, M. ALPASLAN, AND M. AKTAS. 1995. Effect of salinity stress on stomatal resistance, proline, chlorophyll and mineral composition of potato. In: Proceedings of the 9th International Symposium of CIEC on Soil Fertility and Fertilizer Management, Turkey.

GUNTZER, F., C. KELLER, AND J.D. MEUNIER. 2011. Benefits of plant silicon for crops: a review. Agron. Sustain. Dev., 32: 201-213. 
GUPTA, B., AND B. HUANG. 2014. Mechanism of salinity tolerance in plants: physiological, biochemical, and molecular characterization, J. Genom., 118.

HAGHIGHI, M., AND M. PESSARAKLI. 2013. Influence of Silicon and Nano-silicon on Salinitytolerance of Cherry Tomatoes (Solanum lycopersicum L.) at Early Growth Stage, Sci. Hort., 161: 111-117.

HAGHIGHI, Z., N. KARIMI, M. MODARRESI, AND S. MOLLAYI. 2012. Enhancement of compatible solute and secondary metabolites production in Plantago ovata Forsk by salinity stress, J Med Plants Res., 6: 3495-3500

HAMMER, O., D.A.T. HARPER, AND P.D. RYAN. 2001. PAST: Paleontological Statistics Software Package for Education and Data Analysis. Palaeontologia Electronica. 4.

HAN, Y., W. LEI, L. WEN, AND M. HOU. 2015. Silicon-mediated Resistance in a Susceptible Rice Variety to the Rice Leaf Folder, Cnaphalocrocis medinalis Guenée (Lepidoptera: Pyralidae). PLoS ONE, 10, e0120557.

HASANUZZAMAN, M., K. NAHAR, AND M. FUJITA. 2013. Plant response to salt stress and role of exogenous protectants to mitigate salt-induced damages. In: Ahmad, P. et al. (Eds.), Ecophysiology and Responses of Plants under Salt Stress, Springer Science + Business Media.

HIEM, K., A. TAIGLIAFERRO, AND D. BOBILYA, 2002. Flavonoids Antioxidants: Chemistry, Metabolism and Structure- Activity Relationships, J.Nutr. Biochem., 13: 572-584.

INIGUEZ-LUY, F.L., AND M.L. FEDERICO. 2011. The Genetics of Brassica napus L. In: Bancroft I, SchmidtR, editors. Genetics and genomics of the Brassicaceae. Dordrecht, New York,Heidelberg, London: Springer; p. 291-322.

JAMALI, B., S. ESHGHI, AND E. TAFAZOLI. 2015. Mineral Composition of 'Selva' Strawberry Asaffected by Time of Application of Nitric Oxide under Saline Conditions, Hortic.Environ. Biotechnol., 56: 273-279.

JAMIL, M., S.U. REHMAN, K.J. LEE, J.M. KIM, AND H.K. RHA. 2007. Salinity Reduced Growth ps2 Photochemistry and Chlorophyll Content in Radish, Sci. Agric., (Piracicaba, Braz.), 64: 111-118.

JANERO, D.R. 1990. Malondialdehyde and Thiobarbituric Acid Reactivity as Diagnostic Indices of Lipid Peoxidation and Peroxidative Tissue Injury, Free Rad. Biol. and Med., 9: 513-540.

JIANG, M., AND J. ZHANG. 2002. Water Stressinduced Abscisic Acid Accumulation Triggers The Increased Generation of Reactive Oxygen Species and Up-Regulates the Activities of Antioxidant Enzymes in Maize Leaves, J. Exp. Bot., 53: 24012410.

KAFI, M., AND Z. RAHIMI. 2010. Salinity Effects on Germination Properties of Purslane (Portulaca oleracea L.), Iran. J. Field Crop. Res., 8 (4): 615621.

KAFI, M., AND Z. RAHIMI. 2011. Effect of Salinity and Silicon on Root Characteristics, Growth, Water Status, Proline Content and Ion Accumulation of Purslane (Portulaca oleracea L.), Soil Sci. Plant Nutr., 57: 341-347.

KAYA, C., H. KIRNAK, AND D. HIGGS. 2001. Enhancement of Growth and Normal Growth Parameters by Foliar Application of Potassium and Phosphorus in Tomato Cultivars Grown at High (NaCl) Salinity, J. Plant Nutr., 24: 357-367.

KHARE, T., V. KUMAR AND P.B. KAVI KISHOR. 2015. $\mathrm{Na}^{+}$and $\mathrm{Cl}^{-}$ions Show Additive Effects under $\mathrm{NaCl}$ Stress on Induction of Oxidative Stress and The Responsive Antioxidative Defense in Rice, Protoplasma, 251(4), DOI 10.1007/s00709-0140749-2

KUNCHANDY, M.N., AND A. RAO. 1990. Oxygen Radical Scavenging Activity of Curcumin, Int. J. of Pharmacog., 58: 237-240.

LEE, D.H., Y.S. KIM, AND C.B. LEE. 2001. The Inductive Response of The Antioxidant Enzymes by Salt Stress in The Rice (Oryza sativa L.), J. Plant Physiol., 158: 737-745.

LEE, S.K., E.Y. SOHN, M. HAMAYUN, J.Y. YOON, AND I.J. LEE. 2010. Effect of Silicon Ongrowth and Salinity Stress of Soybean Plant Grown under Hydroponic System, Agrofor. Syst., 80, 333-340.

LIANG, Y. 1999. Effects of Silicon on Enzyme Activity and Sodium, Potassium and Calcium Concentration in Barley under Salt Stress, Plant Soil, 209: 217-224.

LIANG, Y., M. NIKOLIC, R. BÉLANGER, H. GONG AND A. SONG. 2015. Silicon in Agriculture: From Theory to Practice. Dordrecht: Springer Netherlands.

LIANG, Y.C., Q.R. SHEN, Z.G. SHEN AND T.S. MA. 1996. Effects of Silicon on Salinity Tolerance of two Barley Cultivars, J. Plant Nutr., 19: 173-183.

Lichtenthaler, H.K. 1987. Chlorophylls and Carotenoids: Pigments of Photosynthetic Biomembranes. In Methods in Enzymology, Vol. 148, pp. 350-183. Academic press, Orlando, Fl., USA.

LONG, L.H., P.J. EVANS, AND B. HALLIWELL. 1999. Hydrogen Peroxide in Human Urine: Implications for Antioxidant Defense and Redox Regulation, Biochem Biophys Res Commun., 262: 605-609.

LOWRY, O.H., N.J. ROSEBROUGH, A.L. FARR. AND R.J. RANDALL. 1951. Protein measurement with Folin phenol reagent, J. Biol. Chem., 193: 265275.

MA, J.F. AND N. YAMAJI. 2006. Silicon Uptake and Accumulation in Higher Plants, Trends Plant Sci., 11: $1-6$.

MANDHANIA, S., S. MADAN, AND V. SAWHNEY. 2006. Antioxidant Defense mechanism under Salt Stress in Wheat Seedlings, Biol Plant., 50: 227-231.

MANE, A.V., G.D. SARATALE, B.A. KARADGE AND J.S. SAMANT. 2011. Studies on The Effects of Salinity on Growth, Polyphenol Content and Photosynthetic Response in Vetiveria Zizanioides (L.) Nash Emir, J Food Agric., 23: 59-70

MARSCHNER, H. 1995. Part I. Nutritional Physiology In: Marschner, H. (Ed.), Mineral Nutrition of Higher 
Plants, second ed. Academic Press, London, pp. 313: 18-30

MEDELLÍN-AZUARA, J., R.E. HOWITT, E. HANAK, J.R. LUND, AND W.E. FLEENOR, 2014. Agricultural losses from Salinity in Califo-rnia's Sacramento-San Joaquin Delta, San Fran Est Water Sci., 12: 1-16.

MINGUEZ-MOSQUERA, M.I., M. JAREN-GALAN, AND J. GARRIDO-FERNANDEZ. 1993. Lipoxygenase activity during pepper ripening and processing of paprika, Phytochemistry, 32: 11031108.

MIYAKE, Y. 1992. The Effect of Silicon on The Salt Tolerance of Cucumber and Tomato Plants, Scientific Reports of the Faculty of Agriculture, vol. 80. Okayama University, pp. 93-99.

MORENO, M.I.N., M.I. ISLA, A.R. SAMPIETRO, AND M.A. VATTUONE. 2000. Comparison of The Free Radical Scavenging Activity of Propolis from Several Regions of Argentina, J. Ethnophar-macol., 71: 109-114.

MUNNS, R., AND M. TESTER. 2008. Mechanisms of Salinity Tolerance, Annu Rev Plant Biol., 59: 651681.

NAVARRO, J.M., P. FLORES, C. GARRIDO, AND V. MARTINEZ. 2006. Changes in the Contents of Antioxidant Compounds in Pepper Fruits at Different Ripening Stages, as Affected by Salinity. Food Chem. 96: 66-73.

NEDJIMI, B., Y. DAOUD, AND M. TOUATI. 2006. Growth, Water Relations, Proline and Ion Content of Invitro Cultured Atriplex halimus sub sp. Schweinfurthii as Affected by $\mathrm{CaCl}_{2}$, Commun. Biometry Crop Sci., 1: 79-89.

OMAR, M.S., D.P. YOUSEF, A.M. AL-JIBOURI, M.S. AL-RAWI, AND M.K. HAMEED. 1993. Effects of Gamma Rays and Sodium Chloride on Growth and Cellular Constituents of Sunflower (Helianthus annuus L.) Callus Cultures, J Islamic Acad Sci., 6(1): 69-72.

OUELlETTE, S., M-H. GOYETTE, C. LABBÉ, J. LAUR, L. GAUDREAU, A. GOSSELIN, M. DORAIS, R.K. DESHMUKH, AND R.R. BÉLANGER. 2017. Silicon Transporters and Effects of Silicon Amendments in Strawberry under High Tunnel and Field Conditions, Front. Plant Sci. 8: 949. doi: 10.3389/fpls.2017.00949

OYAIZU, M. 1986. Studies on Product of Browning Effect Reaction Prepared from Glucose Amine, J. Nutr., 44: 307-315.

PARIHAR, P., S. SINGH, R. SINGH, V.P. SINGH AND S.M. PRASAD. 2015. Effect of Salinity Stress on Plants and its Tolerance Strategies: a review, Environ Sci Pollut Res., 22: 4056-4075

PESSARAKLI, M., AND I. SZABOLCS. 2010. Soil Salinity and Sodicity as Particular Plant/Cropstress Factors. In: Pess arakli, M. (Ed.), Handbook of Plant and Crop Stress. Third ed. CRC Press, Boca Raton, pp. 3-21.

PRIETO, P., M. PINEDA, AND M. AGUILAR. 1999. Spectrophotometric quantitation of antioxidant capacity through the formation of a phosphomo- lybdenum complex: specific application to the determination of vitamin E, Anal. Biochem., 269: 337-341.

PURTY, R.S., G. KUMAR, S.L. SINGLA-PAREEK AND A. PAREEK. 2008. Towards salinity tolerance in Brassica: an overview, Physiol Mol Biol Plants., 14: 39-49.

QADIR, M., A.S. QURESHI, AND S.A.M. CHERAGHI. 2008. Extent and Characterisation Ofsalt-Affected Soils in Iran and Strategies for their Amelioration Andmanagement, Land Degrad. Dev., 19: 214-227.

RUI, L., S.WEI, C. MU-XIANG, J. CHENG-JUN, W. MIN, AND Y. BO-PING. 2009. Leaf Anatomical Changes of Burguiera Gymnorrhiza Seedlings under Salt Stress, J. Trop. Subtrop. Bot., 17: 169-175.

SAIRAM, R.K., K. VEERABHADRA RAO AND G.C. SRIVASTAVA. 2002. Differential Response of Wheat Genotypes to Long Term Salinity Stress in Relation to Oxidative Stress, Antioxidant Activity and Osmolyte Concentration, Plant Sci., 163: 1037 1046.

SHAHID, S.A. 2013. Developments in Soil Salinity Assessment, Modeling, Mapping, and Monitoring from Regional to Submicroscopic Scales. Developments in Soil Salinity Assessment and Reclamation. Springer, The Netherlands, pp. 3-43.

SHANKER, A.K., M. DJANAGUIRAMAN, R. SUDHAGAR, C.N. CHANDRASHEKAR, AND G. PATHMANABHAN. 2004. Differential AntiOxidative Response of Ascorbate Glutathione pathway enzymes and metabolites to Chromium Speciation Stress in Green Gram (Vigna radiata (L.) R. Wilczek. cv $\mathrm{CO}_{4}$ roots, Plant Sci., 166: 10351043.

SHEKARI, F., A. ABBASI, AND S.H. MUSTAFAVI. 2015. Effect of Silicon and Selenium Onenzymatic Changes and Productivity of Dill in Saline Condition, J. Saudi Soc.Agric. Sci.

SINGH, A.K., R.A. SINGH, AND S. KUMAR. 2008. Influence of Salinity on Seedling Growth and Metabolism in Maize Genoytypes, Indian J Plant Physiol., 13: 95-99.

SINGH, J., P.C. SHARMA, S.K. SHARMA, AND M. RAI. 2014. Assessing the Effect of Salinity on The Oil Quality Parameters of Indian Mustard (Brassica juncea L. Czern and Coss) using Fourier Transform Near-Infrared Reflectance (FT-NIR) spectroscopy, Grasas Aceites., 65: 1-8.

SINGLETON, V.L., AND J.A. ROSSI. 1965. Colorimetry of Total Phenolics with Phosphomolybdic Phosphotungstic Acid Reagents, Ame. J. Enol. and Viticult., 16: 144-158.

SOLECKA, D. 1997. Role of Phenyl Propanoid Compounds in Plant Responses to Different Stress Factor, Acta Physiol. Plant, 19: 257-268.

SONAR, B.A., M.D. NIVAS, D.K. GAIKWAD, ANDP.D. CHAVAN. 2011. Assessment of SalinityInduced Antioxidative Defense System in Colubrina Asiatica Brong, J Stress Physiol Biochem., 7: 193-200

TAHIR, M.A., RAHMATULLAH T. AZIZ., M. 
ASHRAF, S. KANWAL AND A. MUHAMMAD, 2006. Beneficial Effects of Silicon in Wheat under Salinity Stress Pot Culture, Pak. J. Bot., 38: 17151722.

TATIANA, Z., K. YAMASHITA, AND H. MATSUMOTO. 1999. Iron Deficiency Induced Changes in Ascorbate Content and Enzyme Activities Related to Ascorbate Metabolism in Cucumber Roots, Plant Cell Physiol., 40: 273-280.

TAVALLALI, V., M. RAHEMI, S. ESHGHI, B. KHOLDEBARIN, AND RAMEZANIAN. 2010. Zinc Alleviates Salt Stress and Increases Antioxidant Enzyme Activity in The Leaves of Pistachio (Pistacia vera L. 'Badami') seedlings, Turk J Agr For., 34(4): 349-359.

WANG, S.Y., AND G.J. GALLETTA. 1998. Foliar Application of Potassium Silicate Induces Metabolic Changes in Strawberry Plants, J. Plant Nutr., 21: 157-167.

WANG, T., R. JONSDOTTIR, AND G. ÓLAFSDÓTTIR. 2009. Total Phenolic Compounds, Radical Scavenging and Metal Chelation of Extracts from Icelandic Seaweeds, Food chem., 116: 240-248.

WANG, W., B. VINOCUR, AND A. ALTMAN. 2003. Plant Responses to Drought, Salinity and Extreme Temperatures: Toward Genetic Engineering for Stress Tolerance, Planta., 218(1): 1-14.

WINKEL-SHIRLEY, B. 2002. Biosynthesis of Flavonoids and Effects of Stress, Curr. Opin. Plant
Biol., 5: 218-223.

YAGHUBI, K., N. GHADERI, Y. VAFAEE, AND T. JAVADI. 2016. Potassium Silicate Alleviates Deleterious Effects of Salinity on Two Strawberry Cultivars Grown under Soilless Pot culture, Sci. Hortic. 213, 87-95. 10.1016/j.scienta.2016.10.012

YAZICI, I., I. TURKAN, A.H. SEKMEN, AND T. DEMIRAL. 2007. Salinity Tolerance of Purslane (Portulaca oleracea L.) is Achieved by Enhanced Antioxidative System, Lower Level of Lipid PerOxidation and Proline Accumulation, Environ. Exp. Bot., 61: 49-57.

YEO, A.R., M.E. YEO, S.A. FLOWERS AND T.J. FLOWERS. 1990. Screening of Rice (Oryza sativa L.) Genotypes for Physiological Characters Contributing to Salinity Resistance, and their Relationship to Overall Performance, Theor. Appl. Gen., 79: 377-384.

ZAPATA, N., M. VARGAS, J.F. REYES, AND G. BELMAR. 2012. Quality of Biodiesel and Press Cake Obtainedfrom Euphorbia lathyris, Brassica napus and Ricinus communis, Ind Crop Prod.,38: 15.

ZHU, J.K., P.M. HASEGAWA, AND R.A. BRESSAN. 1997. Molecular Aspects of Osmotic Stress in Plants, Critical Rev Plant Sci., 16(3): 253-277.

ZHU, Z., G. WEI, J. LI, Q. QIAN AND J. YU. 2004. Silicon Alleviates Salt Stress and Increases Antioxidant Enzymes Activity in Leaves of Salt Stressed Cucumber (Cucumis sativus L.), Plant Sci., 167: 527-533. 


\title{
El-Shazoly R. M.
}

\section{التأثير المحسن لعنصر السليكون على صفات النمو والصفات الفسيولوجية والبيوكيميائية لبادرات الكانولا تحت الأجهاد الملحي (Brassica napus L.)}

\author{
رشا محمود سيد حسن الثاذلي \\ قسم النبات و الميكروبيولوجي، كلية العلوم، جامعة الوادي الجديد، \\ الملخص العربي
}

تستهدف الدر اسة الحالية التعرف علي الدور الذي يمكن أن يقوم به عنصر السيليكون (سيليكات الصوديوم بتركيز 1 ملل مول) في تحسين التأثير الضار للإجهاد الملحي (كلوريد الصوديوم بتركيزات 0، 30، 60، 90، 120ملل مول) علي نمو بادرات نبات

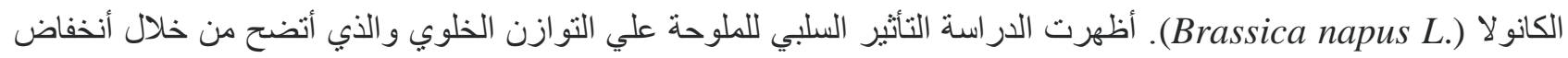
قيم النسب المئوية لكبح الثقوق الحرة وبالأخص النسب المئوية لكبح مجموعة الهيدروكسيل (HO'HOيل كأحد الثقوق الحرة وقيم

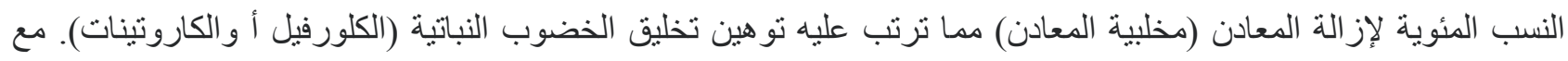
ذلك،اسنطاعت التغذية بعنصر السيليكون أن تحسن من التوازن الخلوي في خلايا بادرات الكانو لا عن طريق رفع قدرة الخلية علي

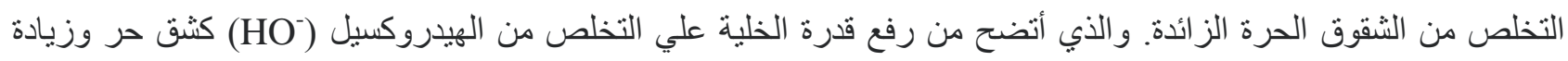
القدرة المخلبية للتخلص من المعادن. بالإضافة إلى ذلك، حافظ السيليكون على سلامة الأغشية منخل الرفع قدرة الخلية علي منع دنع التأكسد للأحماض الدهنية في الاغشية البلازمية. ساعد عنصر السيليكون علي حماية الخلية من ضغوط الأكسدة تحت الاجهاد الملحي عن طريق تحسين النظام (الانزيمي واللاإنزيمي) المضاد للأكسدة. حيث حسن نشاط عدة أنزيمات المضادة للأكسدة (CAT, SOD, APX, POS) 120 ملل مول كلوريد صوديوم. وهكذا يتضح ان عنصر السيليكون لعب دورا هاما في مقاومة الاجهاد الملحي في بادرات نبات الكانو لا من خلال عدة طرق أهمها زيادة قدرة الخلية علي كبح الثنقوق الحرة والتخلص منها ومن ثم تقليل الإجهاد التأكسدي بالخلية. كما لعب السليكون دور او اضحا في حماية الاغشية البلازمية من الأكسدة. الامر الذي انعكس علي معدلات النمو لبادرات الكانو لا من خلال رفع المحتوي من مكونات الأختضاب (الكلوروفيل). الكلمات المفتاحية: الملوحة، السيليكون، الإنزيماتالمضادة للأكسدة، النسبة المئوية لنتيط تأكسد الدهون في الأغشية، النسبة المئوية لكبح الثق الحر HO_النسبة المئوية لإز الة المعادن(مخلبية المعادن). 